\title{
A Contrastive Analysis of Patterns of Grammatical Collocations between the English "Animal Farm" and Its Azeri Turkish Translation
}

\author{
Esmail Faghih \\ Department of English Language, Faculty of Persian Literature and Foreign Languages, Islamic Azad University, South \\ Tehran Branch, Tehran, Iran \\ Mahzad Mehdizadeh \\ Department of English Language, Faculty of Persian Literature and Foreign Languages, Islamic Azad University, South \\ Tehran Branch, Tehran, Iran
}

\begin{abstract}
The present study investigates the patterns of English and Azeri Turkish grammatical collocations in the original English novella "Animal Farm" and its Turkish translation. The specific objective of this study is to identify the similarities and differences of the patterns of English and Azeri Turkish grammatical collocations. To answer the research questions of the study, grammatical collocations throughout the English novella have been identified and categorized on the basis of Benson's (1986b) categorization of English grammatical collocations. The classified English collocations were then compared and contrasted with their Turkish correspondences. As a result of comparison and contrast of these collocations in English and Turkish it became clear that the word order patterns in the grammatical collocations of these two languages are different in most cases. Accordingly, on the basis of the strong version of contrastive analysis it is predicted that learning English grammatical collocations will be troublesome for Iranian Azeri Turkish speakers.
\end{abstract}

Index Terms - collocation, grammatical collocation, lexical collocation

\section{INTRODUCTION}

Collocation is the co-occurrence of words in every natural language. Analyzing languages from different aspects reveals similarities and differences in their structure, grammar, lexis, etc. The differences between languages and the way in which words appear with each other urges the translator to pay special attention to the differences between the languages, their collocations, and patterns of collocations in order to produce a natural and clear translation.

Collocation has gained a high degree of attention over the last decades. Different researchers have focused on various aspects of collocation and have provided definitions and classifications of it. The notion of collocation was first introduced by Firth (1957) who has stated that "you shall know a word by the company it keeps" (p. 168). Firth (1957) has defined collocation "as part of the meaning of a word" (as cited in Carter, 1998). Laufer - Dvorkin (1991, p.19) has pointed out that "knowing a word implies the knowledge of possible combinations into which a given item can enter. Such combinations are called collocations." She (1991) has also mentioned that "collocations are problematic when their meaning is apparent at first glance but their constituent elements cannot be given their translation equivalents" (p.19).

The present study intends to investigate the notion and characteristics of English grammatical collocations and their Azeri Turkish translations. It also aims at identifying the similarities and differences of these collocations in structure and pattern. Specifically, this study addresses the following questions:

1. Is there any changes in the word order of grammatical collocations in the process of translating them from English into Turkish?

2. Is the classification of English grammatical collocations different from Turkish ones?

The study further aims to identify the similarities and differences between the order and patterns of English grammatical collocations selected from the English novella "Animal farm" and its Turkish translation. It is hoped that findings of the present study will be of use for novice translators and students of EFL who are engaged in the translation of collocation. The results of this study will hopefully also be beneficial for those who want to get familiar with how words co-occur in Turkish.

\section{LITERATURE REVIEW}

\section{A. Collocation}


The term collocation is used to refer to specific words which co-occur with each other in particular ways and following specific patterns which may be different from language to language. Below, we will give a brief account of some of the observations by different scholars on collocation.

Cruse (1986) has defined collocation as "sequences of lexical items which habitually co-occur, but which are nonetheless fully transparent in the sense that each lexical constituent is also a semantic constituent" (p.40). Fine weather, light drizzle, high winds, and torrential rain are examples of collocations provided by Cruse (1986, p. 40). Cruse (1986) has also stated that collocations are distinct from idioms in that collocations have a kind of semantic cohesion and "constituent elements are, to varying degrees, mutually selective" (p.40).

Sinclair (1991) has pointed out that "collocation is the co-occurrence of two or more words within a short space of each other in a text. The usual measure of proximity is a maximum of four words intervening" (p.170).

Smadja (1993, p.143) has defined collocation as "recurrent combinations of words that co-occur more often than expected by chance and that corresponds to arbitrary word usages." He (1993) has also argued that all natural languages make use of collocations.

Carter (1998) has described collocation as "a group of words which occur repeatedly in a language" (p.51). According to him (1998), these patterns of co-occurrence can be either grammatical or lexical.

Larson (1998, p.155) has observed that collocation "is concerned with how words go together, i.e., which words may occur in constructions with which other words." According to Larson (1998), combination of some words with each other may occur often, others occasionally, and some others rarely. Larson (1998) has referred to the meaning of the word 'collocate' as "to put side by side" (p.155). He has also maintained that words may collocate with each other in different ways across languages.

Moon (1998) has argued that languages are strongly patterned and words occur in specific lexicogrammatical patterns. She (1998) has continued that "collocation typically donates frequently repeated or statistically significant cooccurrences, whether or not there are any special semantic bound between collocating items" (p.26). According to her (1998), collocations are lexical evidences which indicate that words are not combined randomly, but follow certain rules and principles.

Hatim and Munday (2004) have defined collocation as "the way that words are typically used together" (p.249). They (2004) have provided two examples of collocation which are pretty woman and handsome man and have maintained that they are examples of typical (strong) collocation in English. They (2004) have further conveyed that this does not imply that handsome woman and pretty man are impossible but they are rather very unusual or marked. Marked collocations as in the example of Hatim and Munday (2004) can be used for the purpose of humor.

Martelli (2007) still another scholar has stated that:

The term collocation is used to indicate the repeated co-occurrence of lexical items. The main assumption behind the idea of collocation is that some words attract each other thus forming natural sounding combinations while other combinations, although acceptable from a syntactic and semantic point of view, are not considered acceptable and are not used. (p.11)

Finally, Cowie (2009, p.49) has mentioned that "a collocation is memorized as a lexical unity, but at the same time it is typically divided in two, both semantically and grammatically." In another definition Cowie (2009) has pointed out that "collocations are combinations of two or more lexical items in a grammatical pattern in which one is used in a literal sense and the other in a figurative sense" (p.122).

\section{B. Classification of Collocation}

Collocation has been studied from different perspectives and accordingly different classifications have been provided by scholars. Since the present study is on the basis of Benson, Benson, and Ilson's (1986b) classification of English collocations, the summary of their work is provided here.

Benson, Benson, and Ilson (1986 as cited in Chaun Li, 2005, p.7) have introduced two types of collocations: lexical and grammatical collocations. According to this classification, lexical collocations are combinations of nouns, verbs, adjectives, and adverbs and are further divided into seven types. Grammatical collocations on the other hand contain a dominant word, such as a noun, a verb, or an adjective and a preposition or grammatical structure. Grammatical collocations are further divided into eight types. Table I provides classification of English grammatical collocations by Benson, Benson, and Ilson (1986b). 
TABLE I

GRAMMATICAL COLLOCATION ACCORDING TO BENSON, BENSON, AND ILSON(1986B)

\begin{tabular}{|c|c|c|}
\hline Type & Pattern & Example \\
\hline G1 & Noun + Preposition & $\begin{array}{l}\text { a blockade against, a claim for, a pride } \\
\text { in }\end{array}$ \\
\hline G2 & Noun + to + Infinitive & an attempt to do it \\
\hline G3 & Noun + that-clause & $\begin{array}{l}\text { He took an oath that he would do his } \\
\text { duty. }\end{array}$ \\
\hline G4 & Preposition + Noun & by accident, in advance \\
\hline G5 & Adjective+ preposition & angry at, full of, fond of \\
\hline G6 & Adjective + to + Infinitive & ready to go, heavy to lift \\
\hline G7 & Adjective + that-clause & $\begin{array}{l}\text { She was afraid that she would fail the } \\
\text { exam. }\end{array}$ \\
\hline G8(A) & $\begin{array}{l}\text { Verb+ direct object }+ \text { to }+ \text { indirect object }=\mathrm{V}+ \\
\text { indirect } \mathrm{O}+\operatorname{direct} \mathrm{O}\end{array}$ & $\begin{array}{l}\text { She sent the book to him. } \\
=\text { She sent him the book. }\end{array}$ \\
\hline G8(B) & $\mathrm{Verb}+\operatorname{direct} \mathrm{O}+$ to + indirect $\mathrm{O}$ & They mentioned the book to her. \\
\hline $\mathrm{G} 8(\mathrm{C})$ & $\begin{array}{l}\text { Verb }+\operatorname{direct} O+\text { for }+ \text { indirect } O \\
=\text { Verb }+ \text { indirect } O+\operatorname{direct} O\end{array}$ & $\begin{array}{l}\text { She bought a shirt for her husband = } \\
\text { She bought her husband a shirt. }\end{array}$ \\
\hline G8(D) & Verb + preposition + Object & $\begin{array}{l}\text { They came by train. call at, protest } \\
\text { against }\end{array}$ \\
\hline G8(d) & $\mathrm{Verb}+\mathrm{O}+$ preposition $+\mathrm{O}$ & We invited them to the meeting. \\
\hline G8(E) & Verb + to + Infinitive & She continued to work. \\
\hline $\mathrm{G} 8(\mathrm{~F})$ & Verb + bare infinitive & Mary had better go. \\
\hline $\mathrm{G} 8(\mathrm{G})$ & Verb + V-ing & They enjoy watching TV. \\
\hline $\mathrm{G} 8(\mathrm{H})$ & Verb + Object + to Infinitive & We forced them to leave. \\
\hline G8(I) & Verb + Object + infinitive & She heard them leave. \\
\hline G8(J) & Verb + Object + V-ing & He felt his heart beating. \\
\hline $\mathrm{G} 8(\mathrm{~K})$ & Verb + a possessive + V-ing & I cannot image their staling apples. \\
\hline G8(L) & Verb + that clause & $\begin{array}{l}\text { The doctor suggests me that I take } \\
\text { Vitamins. }\end{array}$ \\
\hline G8(M) & Verb $+\mathrm{O}+$ to be + Complement & We consider her to be well-trained. \\
\hline $\mathrm{G} 8(\mathrm{~N})$ & Verb $+\mathrm{O}+$ Complement & She dyed her hair red. \\
\hline $\mathrm{G} 8(\mathrm{O})$ & Verb + Object $1+$ Object 2 & The teacher asked the pupil a question. \\
\hline G8(P) & Verb $+(\mathrm{O})+$ Adverbial & He carried himself well. \\
\hline G8(Q) & Verb $+(\mathrm{O})+$ wh-clause/ wh-phrase & She asked why we had come. \\
\hline G8(R) & $\begin{array}{l}\text { It }+ \text { Verb }+ \text { Object }+ \text { to infinitive } \\
\text { It }+ \text { V + Object }+ \text { that-clause }\end{array}$ & $\begin{array}{l}\text { It surprised me to learn of her } \\
\text { decision. } \\
\text { It surprised me that our offer was } \\
\text { rejected. }\end{array}$ \\
\hline $\begin{array}{l}\text { G8(S) } \\
\text { G8(s) }\end{array}$ & $\begin{array}{l}\mathrm{V}+\text { Complement (Adjective or Noun) } \\
\mathrm{V}+\text { Complement (Adjective) }\end{array}$ & $\begin{array}{l}\text { He was a teacher. } \\
\text { The food tastes good. }\end{array}$ \\
\hline
\end{tabular}

Adapted from Benson, Benson, and Ilson (1986b, as cited in Chaun Li, 2005, p.8)

\section{Azeri Turkish}

As mentioned earlier the present study aims at investigating the similarities and differences between patterns of grammatical collocations in English and Azeri Turkish. As a result, a description of the later language is provided here. Azeri Turkish is one of the dominant languages spoken in Iran. It belongs to the agglutinative family of Ural-Altaic languages and is believed to be one of the major offsprings of the south western Oghuz languages. Anatolian or 
Ottoman Turkish is the other major subdivision which is spoken in Turkey. Katamba (2006) has stated that Turkish is considered to be one of the agglutinating languages in which there is "a more or less one-to-one matching of morphemes with morphs" (p.61). He (2006, p. 59) has provided an example of this feature of Turkish:

el 'the hand'
elim 'my hand', elimde
eler 'the hands'
Morpheme:
ellerim

Berengian (2006) has used the term "Azerbaijani" as a branch and descendent of Oghuz Turkic. She (2006) has stated that the oldest use of the term Azerbaijani referring to a unique language goes back to 10th to 13th century. When in the 19th century, the study of Eastern languages drew the attention of western scholars the term Azerbaijani was used to represent Oghuz Turkic or Azerbaijani Turkish.

Different dialects of Turkish language are widely spoken in many parts of Iran. This language is also spoken in the republic of Azerbaijan, Turkey, southern Dagestan, Armenia, Estonia, Georgia, Kazakhstan, Kyrgyzstan, Russia, Turkmenistan, Uzbekistan, Afghanistan, Iraq, Jordan, Syria, and even USA. Mohammad Panaah (2008, p. 4) has observed that the number of people speaking Turkish goes beyond 200 million, who are living in different countries from east of Siberia to Balkans in Europe. Nowadays in the republic of Azerbaijan Turkish language is written in Roman alphabet. However, in Iran infinitesimal numbers of Azeris have been able to develop the ability to read and write in their mother tongue since the language of education in this country is Farsi. Therefore, in Iran Turkish, if at all, is written in Farsi alphabet which is a version of Arabic orthography.

\section{METHODOLOGY}

\section{A. The Present Study}

The present study attempts to investigate the similarities and differences between patterns of grammatical collocations in English and Azeri Turkish. To achieve the objective of this study, grammatical collocations have been selected from the original English novella "Animal Farm" and categorized on the basis of Benson's (1998b) classification of English grammatical collocations. The corresponding Turkish counterparts were then identified in the Turkish translation and were next compared and contrasted with the English collocations. Before presenting the analyses of the extracted data, a brief definition of the materials and procedures applied in this research seems necessary.

\section{B. Method}

This study aimed at extracting English grammatical collocations from the original English novella on the basis of Benson's (1998b) classification of English grammatical collocations and comparing and contrasting them with their Azeri Turkish translations.

\section{Source Materials}

In order achieve the objective of this study, the English Novella "Animal Farm" by George Orwell was selected as the source material and its grammatical collocations were compared and contrasted with its translation by Vilayat Quliyev into Azeri Turkish. The Azeri Turkish version of this book used in this research was edited and published by Akbar Rahimzad Faraci in 2010 under the title of "Heyvanlar Qalasi” by Akhtar publishing house in Tabriz, Iran.

\section{Procedures}

English grammatical collocations in the original English novella were identified and categorized on the basis of Benson's (1986) category of English collocations and with resort to English dictionaries of collocations. The corresponding Turkish items were then identified in the Azeri Turkish translation. The next step was to utilize Turkish dictionaries in order to ascertain the parts of speech of different components of the categorized collocations. Finally, the classified English grammatical collocations and their Azeri Turkish translations were compared and contrasted to reveal the similarities and differences between their patterns and word order.

\section{ANALYSIS}

To achieve the objective of the present study, grammatical collocations throughout the original novella have been identified and categorized based on Benson's (1986b) category of collocation. That is to say 734 grammatical collocations have been extracted from the text and placed in 27 related categories. Comparing and contrasting these collocations with their Turkish equivalents revealed some similarities and differences in their patterns and word order. Table II presents the patterns of English grammatical collocations in the original English novella and the most frequent patterns in which Turkish collocations appeared in the Turkish translation. It also summarizes the similarities and 
differences which have been observed in comparison and contrast of patterns of English and Turkish grammatical collocations.

TABLE II.

PATTERNS OF ENGLISH AND TURKISH GRAMMATICAL COLLOCATIONS

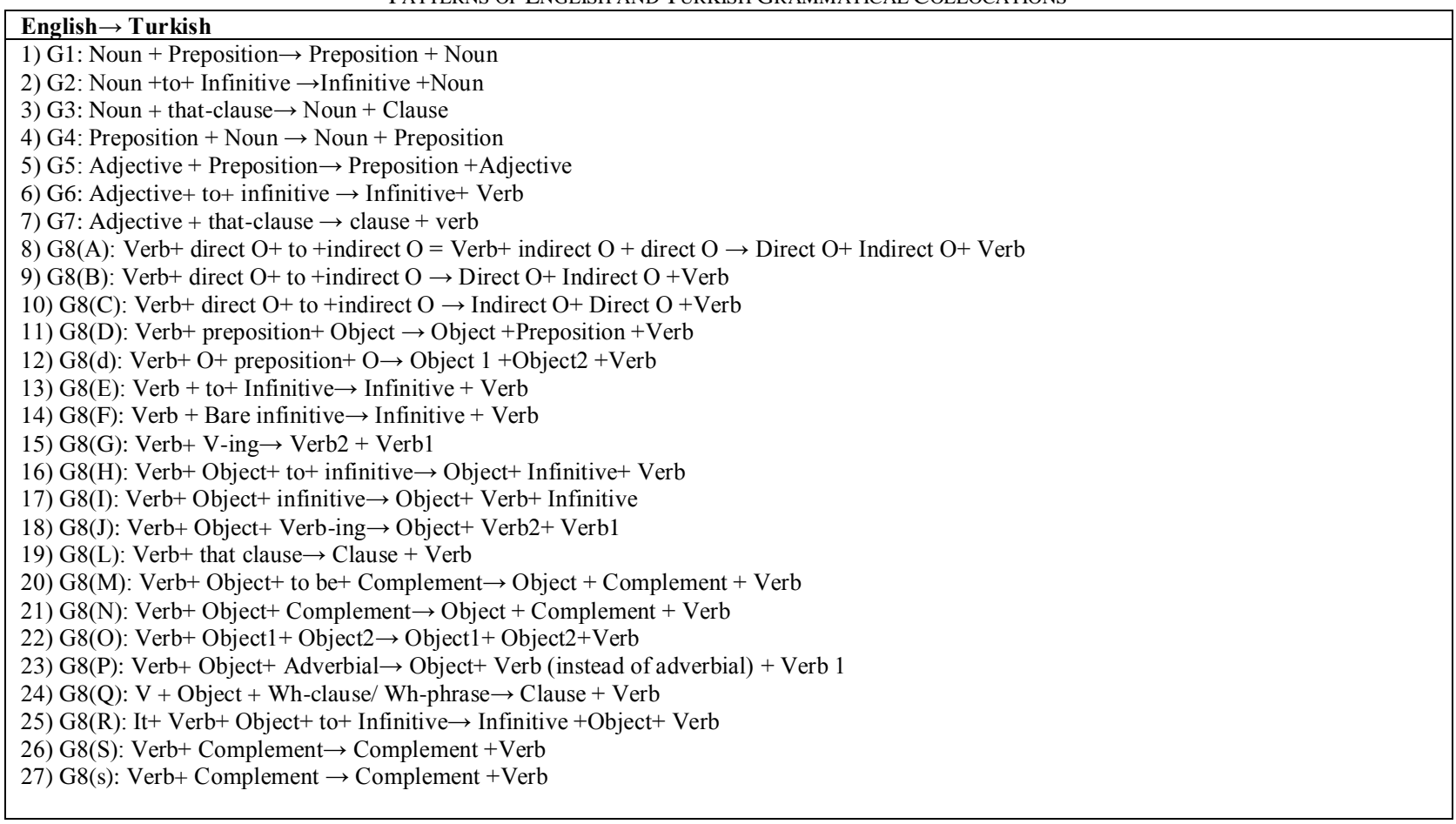

As presented in table II, the differences in the orders of the words which constitute the English and Turkish grammatical collocations indicate that grammatical collocations in English and Turkish follow different patterns and in almost all of the categories we face an alteration of word order. The only exception in which English and Turkish grammatical collocations seem to follow similar patterns is grammatical collocation type 3 . It can therefore be concluded that among 27 categories of English grammatical collocations extracted from the original English novella and its Azeri Turkish translation, 26 categories followed different patterns in these two languages.

Since the number of grammatical collocations which were studied in this research was high, only some examples are provided here to present the similar and different patterns in which English and Turkish grammatical collocations appear. Tables III and IV present examples of grammatical collocations type 3 and type 8(D) selected at random with similar and different patterns in English and Turkish respectively. It is worth mentioning that in this research LC transliteration system is used in order to transliterate Azeri Turkish collocations.

TABLE III.

EXAMPLES OF ENGLISH AND TURKISH GRAMMATICAL COLLOCATIONS TYPE3

\begin{tabular}{|c|c|}
\hline English (Noun + that-clause) & Turkish (Noun + Clause ) \\
\hline $\begin{array}{l}\text { 1. The very day (noun) that the great muscles of yours lose their } \\
\text { power, Jones will sell you to a knacker }\end{array}$ & 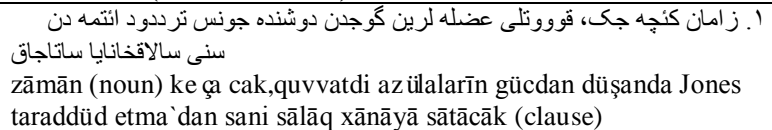 \\
\hline $\begin{array}{l}\text { 2. Do you give me your word of honor (noun) that that man was } \\
\text { not stroking your nose? }\end{array}$ &  \\
\hline
\end{tabular}

Grammatical collocation type3 happened 16 times in the original English novella. Comparing and contrasting these collocations with their Turkish equivalents showed that 10 of these collocations were translated into Turkish with the nouns at the beginning and the clauses in question followed them. There were also instances where the clauses were placed at the beginning and the nouns were following them or the nouns were totally deleted. In addition, the analysis revealed that, the Turkish version did not have the corresponding word to the English THAT. However, since the frequency of nouns followed by clauses is more than clauses followed by nouns it can be inferred that in Turkish, this type of collocation follows a similar pattern as the one in English. 
TABLE IV.

EXAMPLES OF ENGLISH AND TURKISH GRAMMATICAL COLLOCATIONS TYPE 8(D)

\begin{tabular}{|c|c|}
\hline $\begin{array}{l}\text { English } \\
\text { (Verb+ preposition+ Object) }\end{array}$ & $\begin{array}{l}\text { Turkish } \\
\text { (Object +Preposition + Verb) }\end{array}$ \\
\hline $\begin{array}{l}\text { 1....have gone to the market... } \\
\text { 2. ... sprang from his place... } \\
\text { 3. ... remained on his foot... }\end{array}$ & 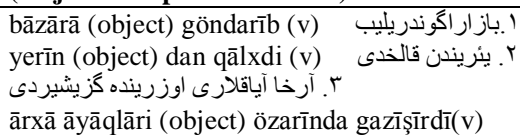 \\
\hline
\end{tabular}

The total number of grammatical collocations type 8(D) in the original novella was 82, among which 76 instances in Azeri Turkish appeared to follow a pattern of "object + preposition + verb". Since the order of this collocation in English is "verb + preposition+ object", it can be realized that collocations of this type follow different patterns in English and Turkish.

\section{RESULTS}

Attempts have been made in the present study to identify, classify, and compare and contrast English grammatical collocations with their Azeri Turkish translations to find out how English grammatical collocations are translated into Turkish.

Specifically, the purpose of this study was to identify and classify English grammatical collocations throughout the original English novella "Animal Farm" and compare and contrast them with their Azeri Turkish translation so as to discover the potential similarities and differences of their patterns of occurrence. To arrive at the objective of this study, 734 English and Turkish grammatical collocations were identified and categorized into 27 categories based on Benson's (1986b) classification of English collocations. (See table II above). Results from comparing and contrasting these collocations with their Turkish equivalents made it clear that the word order pattern changes in 26 categories of grammatical collocations between these two languages. The only category in which the words tend to appear in a similar order in English and Turkish grammatical collocations is grammatical collocation type 3.

Consequently, it can be concluded that:

1. The word order in 26 categories of grammatical collocations changes in the translation of English grammatical collocations into Turkish and grammatical collocations in these two languages appear to follow different patterns in most cases.

2. Since the grammatical collocations in English and Turkish follow different word orders and patterns, it can be concluded that the classification of grammatical collocations in English and Turkish is different from one another. The only exception in which English and Turkish grammatical collocations appear to follow a similar pattern and fall into similar classification is grammatical collocation type 3 .

\section{CONCLUSION}

Analyzing the extracted data and comparing and contrasting grammatical collocations in English "Animal Farm" and its Turkish translation "Heyvanalr Qalasi", it became clear that English and Turkish grammatical collocations tend to appear in different patterns and orders. In other words the number of instances in which differences were observed among patterns of these collocations was much more than the cases in which similarities were detected. This indicates that the collocational patterns and the way in which words appear with each other in these two languages are different. Only one category of English and Turkish grammatical collocations appeared in a more or less similar pattern which was grammatical collocation type 3. Therefore, according to the strong version of contrastive analysis it can be predicted that learning English grammatical collocations will be troublesome for Iranian Azeri Turkish speakers.

\section{REFERENCES}

[1] Baker, M. (2001). In Other Words: A course book on translation. London and New York: Taylor and Francis.

[2] Benson, M., Benson, E. \& Ilson, R. (1986b). The BBI combinatory dictionary of English: A guide to word combinations. Amsterdam: John Benjamins.

[3] Carter, R. (1998). Vocabulary: Applied Linguistic Perspectives (2nd ed.). London: Routledge.

[4] Chaun Li, C. (2005). A Study of Collocational Error Types in ESL/EFL College Learners' Writing. Master's thesis, Ming Chaun University.

[5] Cowie, A. P. (2009). Semantics. Oxford: Oxford University Press.

[6] Cruse, D. A. (1986). Lexical Semantics. Cambridge: Cambridge University Press.

[7] Faghih, E. (Trans.) (2007). Adabiyāt -e- Āzeri ve Fārsi dar Āzerbaijān -e- Iran dar Sadeye Bistom (Azeri And Persian Literary Works In Twentieth Century Iranian Azerbaijan). Berengian, S. (1971). Tehran: Nashre Markaz.

[8] Firth, J. R. (1957). The Techniques of Semantics. Oxford: Oxford University Press.

[9] Hatim, B. and Munday, J. (2004). Translation: An advanced resource book. Oxon: Routledge.

[10] Katamba, F. and Stonham, J. (2006). Morphology (2nd ed.). Hampshire: Palgrave Macmillan.

[11] Larson, M. L. (1998). Meaning- Based Translation: A Guide to Cross- Language Equivalence (2nd ed.). Maryland: University Press of America.

[12] Laufer-Dvorkin, B. (1991). Similar Lexical forms in Interlanguage. Tübingen: Gunter Narr Verlag. 
[13] Martelli, A. (2007). Lexical Collocations in Learner English: A Corpus-Based Approach. Alessandria: Edizioni dell'Orso.

[14] Mohammadpanah, B. (2008). Turkān Dar Guzar-i Tārikh. Tehran: Sabzan.

[15] Moon, R. (1998). Fixed Expressions and Idioms in English: A Corpus-Based Approach. Oxford: Oxford University Press.

[16] Orwell, G. (2010). Animal Farm. Tehran: Jangal.

[17] Quliyev, V. (Trans.) (2010). Heyvanlar Qalasi(Animal Farm). Tabriz: Akhtar.

[18] Sinclair, J. (1991). Corpus, Concordance, Collocation. Oxford: Oxford University Press.

[19] Smadja, F. (1993). Retrieving Collocations from Text: Xtract. Cambridge: MIT press.

[20] Sularish, P. (2010). Direct and Indirect Translation of English Collocations into Indonesian. Master's thesis, Gunadarma University.

Esmail Faghih, Ph.D. (U of I) is an Emeritus professor of TEFL and is currently teaching at Islamic Azad University, South Tehran Branch. Professor Faghih has published numerous books and articles on TEFL and translation studies. He is also renowned for his translations.

Mahzad Mehdizadeh was born in Tabriz, Iran. She lives in Tabriz and holds an M.A. in English Translation Studies from Islamic Azad University, South Tehran Branch, Tehran, Iran. She received her B.A. in English Translation and Interpretation from Islamic Azad University of Tabriz, Iran in 2010. She is the corresponding author of this article. 